The Geographical Journal of Nepal

Vol. 14: 151-170, 2021

DOI: https://doi.org/10.3126/gjn.v14i0.35557

Central Department of Geography,

Tribhuvan University, Kathmandu, Nepal

\title{
Assessment of climate change vulnerability in Chiti area of Lamjung district, Nepal
}

\author{
Sher Bahadur Gurung \\ Central Department of Geography, Tribhuvan University \\ Corresponding Email: sherbahadur@gmail.com
}

Received: 24 October, 2020; Accepted: 05 November, 2020; Published: March 2021

\begin{abstract}
Climate change issue is the global concern of the present day. The present study attempts to assess the vulnerability of the community due to climate change for which Chiti area of Besisahar Municipality from Lamjung district of Nepal was selected as the study area. The climate change vulnerability was assessed using the Long Term Research Program (LTRP). The long term climate change vulnerability household surveys from 2013 baseline data to 2016, 2017 and 2019 data were analysed in this study. This study adapted IPCC (2001) methodology i.e. also used by C4 EcoSolutions on their baseline climate change vulnerability assessment. This is a bottom-up, integrative approach that considers both physical and social dimensions at a local level. Consequently, vulnerability is best understood as a function of three components: exposure, sensitivity and adaptive capacity. Exposure to climate change vulnerability is calculated with sum of changes in temperature, changes in rainfall patterns, changes in rainfall intensity, drought episodes and flooding events. Sensitivity is calculated based on slope failures, soil fertility, changes in natural environment (i) soil cover; ii) levels of river sedimentation; iii) water salinity; iv) river ecosystems; v) forest size; and vi) the presence of invasive species), economic dependency level, irrigation facilities and livelihood sources. The major finding is that Chiti has been facing climate change since last decade and it is found severely vulnerable due to climate change. There is an urgent need of improvement on climate change adaptive capacity which could result of awareness, information on climate change and adaptation, surplus production and change in agricultural practices. The present study has used awareness score based on conceptual awareness, experiential awareness, and engagement of household to talk about climate change and adaptation. The Long Term Research Approach is appropriate to assess climate change vulnerability in community level. Climate change awareness is
\end{abstract}


one of the major components to reduce vulnerability to climate change in the research area. This is a post adaptation vulnerability analysis of local community which supports climate change vulnerability adaptation policy.

Keywords: Chiti, climate change vulnerability, exposure, sensitivity and adaptation

\section{Introduction}

Climate change refers to a change of climate that is attributed directly or indirectly due to human activities and vulnerability is the degree to which a system is susceptible to, or unable to cope with, adverse effects of climate change, including climate variability and extremes (IPCC, 2001). According to IPCC report 2018, the organization's strategic concern on limiting global warming to $1.5^{\circ} \mathrm{C}$ compared with projected $2^{\circ} \mathrm{C}$ based on the world temperatures have increased by $1{ }^{\circ} \mathrm{C}$ over the last century. Consequently, extreme occurrences have been increased in Asian region, including floods, droughts, forest fires, and tropical cyclones, as a result decreasing in agricultural productivity, runoff and water availability may decrease, human health would be threatened, sea-level rises, increased intensity of rainfall would increase flood risks, climate change would increase energy demand, decrease tourism attraction, and influence transportation in some regions of Asia, climate change would exacerbate threats to biodiversity due to land-use and land-cover change and population pressure in this region (Hijooka, Lin, Pereira, Corlett, Cui, Insarov, Lasco, Lindgren and Surjan, 2014).

However, in the case of Nepal since 1971 to 2014, the annual maximum and minimum temperature increased $0.056^{\circ} \mathrm{C}, 0.002^{\circ} \mathrm{C}$ respectively and the mean annual rainfall decreased $1.333 \mathrm{~mm}$ per annum (DHM, 2017). There is increasing trend of climate change magnitude with altitude in western Himalaya and that is linked with biodiversity, ecosystem functioning, ecosystem services, drivers of change and human well-being. This region is vulnerable to climate change due to ecological fragility, economic marginality, habitat loss and fragmentation, colonization of invasive species, over exploitation of resources, pollution, nutrient loading and global climate change (Tsering, Sharma, Chettri and Shrestha, 2010). Similarly, the social-ecosystem of low, middle and high mountain of Kaligandaki valley of Nepal Himalaya experienced significant levels of exposure to climate change and are sensitive to change and extreme weather events, but limited capacities to adapt across all spatial scales results in very high social-ecological vulnerability (Pandey \& Bardsley, 2015). In the case of Lamjung district, climate change has differential impact which varies according to location of communities, occupation, general household head, the overall vulnerability largely varies according to well being-status of households (Gentle, Thwaites, Race and Alexender, 2014). 
Over the entire Himalaya region of Nepal, it is expected that agriculture and food security, climate-induced disasters, forest and biodiversity, caste/ethnic group, livelihoods and governance public health, tourism, natural and cultural heritage, urban settlements and infrastructure and water resources etc. are vulnerable to climate change (MoPE, 2017). Therefore, the climate change vulnerability assessment is essential to cope with climate change impacts. Most of the Himalayan region studies were focused on pre-adaptation vulnerability and national to global scale. There is lacking post adaptation vulnerability and local to global scale climate change vulnerability analysis. In these context, the present study attempts to assess the vulnerability of the community to climate change selecting Chiti area of Lamjung district of Nepal which is also site for the Ecosystembased Adaptation through South-South Cooperation (EbA South) under the title "Enhancing Capacity, Knowledge and Technology Support to Build Climate Resilience of Vulnerable Developing Countries".

\section{Methods and materials}

\section{Conceptual consideration}

Vulnerability is the function of exposure, sensitivity and adaptive capacity to climate change (IPCC, 2001). The present study used long term research program (LTRP) approach and adapted IPCC methodology to analyse climate change vulnerability assessment. This methodology was also adopted by $\mathrm{C} 4$ EcoSolutions on their baseline assessment for EBA South project which is bottom-up and integrative approach that considers both physical and social dimensions at a local level. The present research has adopted post vulnerability assessment approach. Altogether, 27 households are selected as respondent who are directly benefited by EbA south project intervention. Almost 27 percent of the respondents were women and 17.2 percent was from highly marginalized Dalit and Chepang community. Two field surveyors were deputed for interview and before survey permission from local authorities such as mayor of Besisahar municipality and chairperson of the 11 ward (Chiti) were taken. Prior to each survey the interviewers introduced themselves politely with a brief introduction to the EBA South project and explained why the survey is being undertaken. The interviewer assured that all the personal information will be kept confidential and no respondent should be forced to answer the questions.

In Nepal, the EbA South Project was implemented in 2013-2019 for which Chiti, Jita and Taksar villages in Lamjung district were selected as piloting sites. One of the project components was to monitor the climate change. The second household survey was carried out during July 21-27, 2016 in Chiti. The same households were surveyed in 2013 for baseline which are used here. Two households who were interviewed from 
Chiti during baseline survey were permanently migrated to Chitwan district which was replaced with similar socio-economic status households. The third household survey was conducted on August 10-21, 2017 and fourth household surveyed during April 4 11, 2019.

Vulnerability is best understood as a function of three components exposure, sensitivity and adaptive capacity (IPCC, 2014). Each of these components is described below.

Exposure is the nature and degree to which a system is exposed to significant climate variations.

Sensitivity is the responsiveness of a system to climatic influences which is shaped by both socio-economic and environmental conditions.

Adaptive capacity is the ability of local communities to cope with a hazard, reorganize their resources and minimize loss at different levels. The main determinant of adaptive capacity is access to resources/capital.

\section{Selection of climate change vulnerability assessment indicators}

This present survey followed the guidelines developed by the project on concept of vulnerability, methods of data collection and calculation of vulnerability index which was also used in baseline survey. Figure 1 shows the conceptual framework and indicators used in assessing the vulnerability mentioned in the guideline.

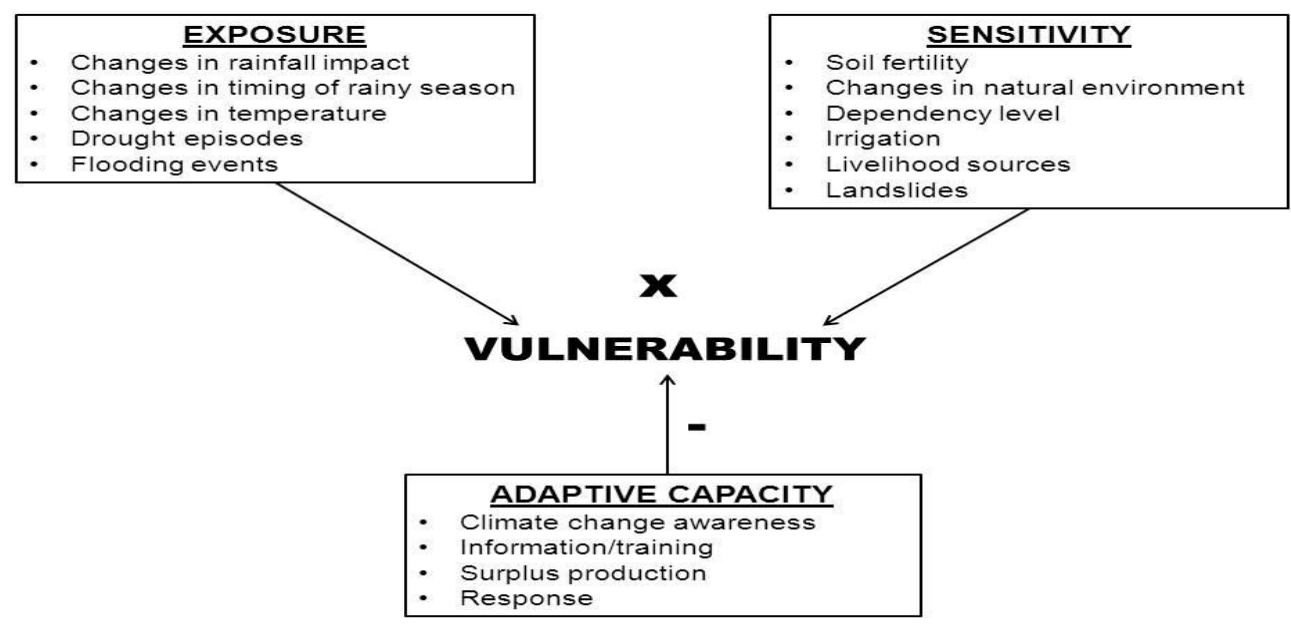

Figure 1: Indicators of climate change vulnerability and their inter-linkages 
Major indicators and their scoring methods used under three different vulnerability components are given in Table 1. Similarly, the indicators and their scoring methods for preparing awareness index are given in Table 2.

The vulnerability index was calculated using the following equations:

The exposure index was calculated as the sum of five indicator scores .

Exposure $=\sum_{i}^{v}$ Scoreindicator $/ \Sigma n$

Exposure to climate change vulnerability is calculated with sum of changes in temperature, changes in rainfall patterns, and changes in rainfall intensity, drought episodes and flooding events. The exposure score is ranges from 0 to 2 . The households or community experiences no changes in temperature, rainfall patterns and intensity, no experiences of drought and flooding are assigned the value 0 . The households felt changes but experienced no noticeable climate change impact are assigned as 1 . The households with increasing climate change exposure value with negative impact are assigned as 2 . The average value of assigned score in exposure index of climate change vulnerability is shown in see table 1 .

The sensitivity index was expressed as the sum of six indicator scores.

Sensitivity $=\sum_{v i}^{v x i}$ score indicator $/ \Sigma n$

Sensitivity is calculated based on Slope failures, Soil fertility, Changes in natural environment: (i) soil cover; ii) levels of river sedimentation; iii) water salinity; iv) river ecosystems; v) forest size; and vi) the presence of invasive species), Economic dependency level, Irrigation facilities and Livelihood sources. In Table 5, the household experiences no slope failure event, no changes in soil fertility and natural vegetations, less than three family members are dependent on household, 100 percent irrigation facility, livelihood dependent on non-agriculture and agriculture was scored 0 . Similarly, households experience slope failure, changes in soil fertility and natural vegetation but there is no negative impact on household, 4-9 family members dependent, partly irrigation and livelihood dependent on more than one crop and livestock were assigned as 1 . Households perceive slope failure, changes in soil fertility and natural vegetation and also experienced negative impact on household, more than 9 family members are dependent, 100 percent rain fed situation and livelihood dependent on single crop or livestock were assigned as 2 . The average value of assigned score is sensitivity index. 
The adaptive capacity index was expressed as the sum of four indicator scores. Adaptive Capacity $=\sum_{x v}^{x i i}$ score indicator $/ \Sigma n$

Climate change adaptive capacity is a result of awareness, information on climate change and adaptation, surplus production and change in agricultural practices. Households with climate change awareness from 0 to 30 percent, they never received information of climate change and adaptation, 100 percent consumed the production, and no remedial action taken for climate change adaptation was scored as 0 . The household climate change awareness is 30 to 60 percent, intermittently receive information of climate change and adaptation, 30 percent surplus production sold, and perceived climate change effect on agricultural production but no changes in agricultural practices were assigned as 1 . The household with 60 to 100 percent awareness household, consistently received the information of climate change and adaption, more than 30 percent surplus production sold and climate change responded by adapting new agricultural practices scored as 2 . The average score of assigned value is adaptive capacity index.

The vulnerability index was expressed as the product of sensitivity and exposure minus adaptive capacity.

Vulnerability $=($ Exposure $x$ Sensitivity $)-$ Adaptive capacity

\section{Awareness assessment}

Awareness score is measured based on conceptual awareness, experiential awareness, and engagement of household to talk about climate change and adaptation. The households were never heard about climate change, did not feel it and never talked about the climate change scored 0 . The households with limited understanding of climate change, personally, they felt effect of climate change and gave some examples and talked about climate change once a month was assigned as 1 . The household understood about drivers of climate change but they were not known the effects and they could give basic examples of personal feeling on climate change relation to weather and hazards and talked about climate change once a week assigned as 2.They understood about drivers of climate change and its effect in depth, gave in-depth examples and talked about climate change more than once a week scored 3. The average score of awareness index is change into the percent.

Similarly, the climate change awareness was calculated as a composite index of three indicators: i) conceptual awareness; ii) experiential awareness; and iii) engagement (Table 2). Scores for climate change awareness were further normalized to range between 
$0-100 \%$ by dividing the scores with the largest possible score (9) and multiplying the quotient by 100 .

$$
\text { Awareness }(\%)=\frac{\text { climate change awareness score }}{9} \times 100
$$

Table 1: Indicators of vulnerability included in the household survey

\begin{tabular}{|c|c|c|c|c|c|}
\hline \multirow{2}{*}{ Index } & \multirow{2}{*}{$\begin{array}{l}\text { Component } \\
\text { indicator }\end{array}$} & \multirow{2}{*}{$\begin{array}{c}\text { Unit of } \\
\text { measurement }\end{array}$} & \multicolumn{3}{|c|}{ Score } \\
\hline & & & $\mathbf{0}$ & 1 & 2 \\
\hline \multirow[t]{5}{*}{ Exposure } & $\begin{array}{l}\text { i) Changes in } \\
\text { temperature. }\end{array}$ & Household. & No change. & $\begin{array}{l}\text { Has increased with no } \\
\text { noticeable negative } \\
\text { effects on household. }\end{array}$ & $\begin{array}{l}\text { Has increased with negative } \\
\text { effects on household. }\end{array}$ \\
\hline & $\begin{array}{l}\text { ii) Changes in } \\
\text { rainfall patterns. }\end{array}$ & Household. & No change. & $\begin{array}{l}\text { Shift in seasons with no } \\
\text { impact on household. }\end{array}$ & $\begin{array}{l}\text { Shift in seasons with } \\
\text { negative impact on } \\
\text { household. }\end{array}$ \\
\hline & $\begin{array}{l}\text { iii) Changes in } \\
\text { rainfall intensity. }\end{array}$ & Household. & No change. & $\begin{array}{l}\text { Increased/decreased } \\
\text { impact of rainfall with no } \\
\text { impact on household. }\end{array}$ & $\begin{array}{l}\text { Increased/decreased impact } \\
\text { of rainfall with negative } \\
\text { effects on household. }\end{array}$ \\
\hline & $\begin{array}{l}\text { iv) Drought } \\
\text { episodes. }\end{array}$ & Household. & $\begin{array}{l}\text { Has not } \\
\text { experienced } \\
\text { drought events in } \\
\text { the recent past. }\end{array}$ & $\begin{array}{l}\text { Has experienced frequent } \\
\text { droughts episodes in } \\
\text { recent past with no } \\
\text { negative effects on } \\
\text { household. }\end{array}$ & $\begin{array}{l}\text { Has experienced frequent } \\
\text { droughts episodes in recent } \\
\text { past with negative effects on } \\
\text { household. }\end{array}$ \\
\hline & $\begin{array}{l}\text { v) Flooding } \\
\text { events. }\end{array}$ & Household. & $\begin{array}{l}\text { Has not } \\
\text { experienced } \\
\text { flooding events in } \\
\text { the recent past. }\end{array}$ & $\begin{array}{l}\text { Has experienced frequent } \\
\text { flooding events in recent } \\
\text { past with no negative } \\
\text { effects on household. }\end{array}$ & $\begin{array}{l}\text { Has experienced frequent } \\
\text { flooding events in recent } \\
\text { past with negative effects on } \\
\text { household. }\end{array}$ \\
\hline \multirow[t]{6}{*}{ Sensitivity } & $\begin{array}{l}\text { vi) Slope } \\
\text { failures. }\end{array}$ & $\begin{array}{l}\text { Household/ local } \\
\text { community. }\end{array}$ & $\begin{array}{l}\text { Household } \\
\text { members reported } \\
\text { no slope failures } \\
\text { around their } \\
\text { village. }\end{array}$ & $\begin{array}{l}\text { Household members } \\
\text { reported slope failures } \\
\text { around their village with } \\
\text { no negative impact on } \\
\text { local community. }\end{array}$ & $\begin{array}{l}\text { Household members } \\
\text { reported slope failures } \\
\text { around their village with } \\
\text { negative impact on local } \\
\text { community. }\end{array}$ \\
\hline & vii) Soil fertility. & Household. & $\begin{array}{l}\text { Household } \\
\text { members report no } \\
\text { change. }\end{array}$ & $\begin{array}{l}\text { Household members } \\
\text { perceive soil fertility } \\
\text { to have decreased with } \\
\text { no negative impact on } \\
\text { family. }\end{array}$ & $\begin{array}{l}\text { Household members } \\
\text { perceive soil fertility to have } \\
\text { decreased with negative } \\
\text { impact on family. }\end{array}$ \\
\hline & $\begin{array}{l}\text { viii) Changes } \\
\text { in natural } \\
\text { environment }^{1} \text {. }\end{array}$ & Household. & $\begin{array}{l}\text { Household } \\
\text { members report no } \\
\text { change. }\end{array}$ & $\begin{array}{l}\text { Experience change with } \\
\text { no negative impact on } \\
\text { household. }\end{array}$ & $\begin{array}{l}\text { Experience change with } \\
\text { negative impact on } \\
\text { household. }\end{array}$ \\
\hline & $\begin{array}{l}\text { ix) Dependency } \\
\text { level }^{2} \text {. }\end{array}$ & Household. & $\begin{array}{l}\text { Household size } \\
\text { is less than three } \\
\text { members. }\end{array}$ & $\begin{array}{l}\text { Household size ranging } \\
\text { from four to nine } \\
\text { members. }\end{array}$ & $\begin{array}{l}\text { Household size of over nine } \\
\text { members. }\end{array}$ \\
\hline & x) Irrigation. & Household. & $100 \%$ Irrigation. & $\begin{array}{l}\text { Part irrigation, part rain } \\
\text { fed. }\end{array}$ & $100 \%$ rain fed. \\
\hline & $\begin{array}{l}\text { xi) Livelihood } \\
\text { sources. }\end{array}$ & Household. & $\begin{array}{l}\text { Household } \\
\text { members utilise } \\
\text { both non- } \\
\text { agricultural } \\
\text { and agricultural } \\
\text { livelihoods. }\end{array}$ & $\begin{array}{l}\text { Household members } \\
\text { rely on more than } \\
\text { one crop type and/or } \\
\text { livestock product for their } \\
\text { livelihoods (agricultural } \\
\text { diversification). }\end{array}$ & $\begin{array}{l}\text { Household members rely } \\
\text { on only one crop type and/ } \\
\text { or livestock product for their } \\
\text { livelihoods. }\end{array}$ \\
\hline $\begin{array}{l}\text { Adaptive } \\
\text { capacity }\end{array}$ & xii) Awareness3. & Household. & $\begin{array}{l}\text { Household } \\
\text { representative has } \\
\text { awareness index of } \\
0-30 \% \text {. }\end{array}$ & $\begin{array}{l}\text { Household representative } \\
\text { has awareness index of } \\
30-60 \% \text {. }\end{array}$ & $\begin{array}{l}\text { Household representative } \\
\text { has awareness index of } \\
60-100 \% .\end{array}$ \\
\hline
\end{tabular}




\begin{tabular}{|l|l|l|l|l|l|}
\hline & $\begin{array}{l}\text { xiii) } \\
\text { Information. }\end{array}$ & Household. & $\begin{array}{l}\text { Household } \\
\text { representative } \\
\text { never receives } \\
\text { information on } \\
\text { climate change and } \\
\text { adaptation. }\end{array}$ & $\begin{array}{l}\text { Household representative } \\
\text { receives information } \\
\text { on climate change and } \\
\text { adaptation intermittently. }\end{array}$ & $\begin{array}{l}\text { Household representative } \\
\text { consistently receives } \\
\text { information on climate } \\
\text { change and adaptation. }\end{array}$ \\
\hline & $\begin{array}{l}\text { xiv) Surplus } \\
\text { production. }\end{array}$ & Household. & $\begin{array}{l}\text { Household's total } \\
\text { food production } \\
\text { is used for own } \\
\text { consumption } \\
\text { (100\% own } \\
\text { consumption). }\end{array}$ & $\begin{array}{l}\text { Less than 30\% of } \\
\text { household's total food } \\
\text { production is sold. }\end{array}$ & $\begin{array}{l}\text { More than } 30 \% \text { of } \\
\text { household's total food } \\
\text { production is sold. }\end{array}$ \\
\hline & $\begin{array}{l}\text { xv) Response: } \\
\text { change in } \\
\text { agricultural } \\
\text { practices. }\end{array}$ & Household. & $\begin{array}{l}\text { Household } \\
\text { members have } \\
\text { not perceived any } \\
\text { changes in the } \\
\text { climate and have } \\
\text { not taken any } \\
\text { remedial action. }\end{array}$ & $\begin{array}{l}\text { Household members } \\
\text { have perceived climate } \\
\text { variability and its related } \\
\text { effects on production } \\
\text { and income but have not } \\
\text { changed their agricultural } \\
\text { practices. }\end{array}$ & $\begin{array}{l}\text { Household members have } \\
\text { perceived climate variability } \\
\text { and its related effects on } \\
\text { production and income and } \\
\text { have therefore responded by } \\
\text { adopting new agricultural } \\
\text { practices (e.g. seed change). }\end{array}$ \\
\hline
\end{tabular}

Table 2: Scores used to calculate climate change awareness

\begin{tabular}{|l|l|l|l|l|l|l|}
\hline $\begin{array}{l}\text { Component } \\
\text { indicator }\end{array}$ & $\begin{array}{l}\text { Unit of } \\
\text { measurement }\end{array}$ & Question & \multicolumn{4}{|c|}{ Score } \\
\cline { 4 - 6 } $\begin{array}{l}\text { i) Conceptual } \\
\text { awareness }\end{array}$ & Individual & $\begin{array}{l}\text { What is } \\
\text { climate } \\
\text { change? }\end{array}$ & $\begin{array}{l}\text { Never } \\
\text { heard } \\
\text { of it }\end{array}$ & $\begin{array}{l}\text { Heard of it, but } \\
\text { have limited } \\
\text { understanding }\end{array}$ & $\begin{array}{l}\text { Understand } \\
\text { the drivers } \\
\text { but not the } \\
\text { effects }\end{array}$ & $\begin{array}{l}\text { Understand } \\
\text { the drivers } \\
\text { (human) and } \\
\text { the effects } \\
\text { (on sectors) } \\
\text { in depth }\end{array}$ \\
\hline $\begin{array}{l}\text { ii) } \\
\text { Experiential } \\
\text { awareness }\end{array}$ & Individual & $\begin{array}{l}\text { Have you } \\
\text { personally } \\
\text { felt the } \\
\text { effect of } \\
\text { climate } \\
\text { change? }\end{array}$ & $\begin{array}{l}\text { No/not } \\
\text { sure }\end{array}$ & $\begin{array}{l}\text { Possibly, gives } \\
\text { examples } \\
\text { relating to } \\
\text { weather and } \\
\text { hazards }\end{array}$ & $\begin{array}{l}\text { Yes, gives } \\
\text { basic } \\
\text { examples } \\
\text { relating to } \\
\text { weather and } \\
\text { hazards }\end{array}$ & $\begin{array}{l}\text { Yes, gives } \\
\text { in-depth } \\
\text { examples of } \\
\text { long term } \\
\text { changes } \\
\text { impacting } \\
\text { on numerous } \\
\text { sectors }\end{array}$ \\
\hline $\begin{array}{l}\text { iii) } \\
\text { Engagement }\end{array}$ & Individual & $\begin{array}{l}\text { Do you } \\
\text { talk about } \\
\text { climate } \\
\text { change } \\
\text { often? }\end{array}$ & Never & $\begin{array}{l}\text { Rarely (maybe } \\
\text { once a month) }\end{array}$ & $\begin{array}{l}\text { Sometimes } \\
\text { (maybe once } \\
\text { a week) }\end{array}$ & $\begin{array}{l}\text { Often (more } \\
\text { than once a } \\
\text { week) }\end{array}$ \\
\hline
\end{tabular}




\section{Study Area}

Chiti area of Besisahar Municipality of Lamjung district (Figure 2) is selected as the study area which is a small watersheds used for EbA South project. The area is dominated by middle mountains. The dominant ( 46.74 percent) landform of the study area is moderate to steep sloping terrain followed by steeply to very steep sloping mountainous terrain. Similarly, the ancient lakes and river terraces (tars); alluvial plains, and fans (depositional) occupy 23.79, 23.28 and 6.19 percent area respectively (Table 3). The area is highly vulnerable to climate change effects including soil erosion, landslides, floods, droughts and glacial lake floods. The site is located at an altitude of about 6701260 meters above the mean sea level, ranging the slope in between $7^{0}-52^{\circ}$. The major rivers are Marsayangdi and Dordi.

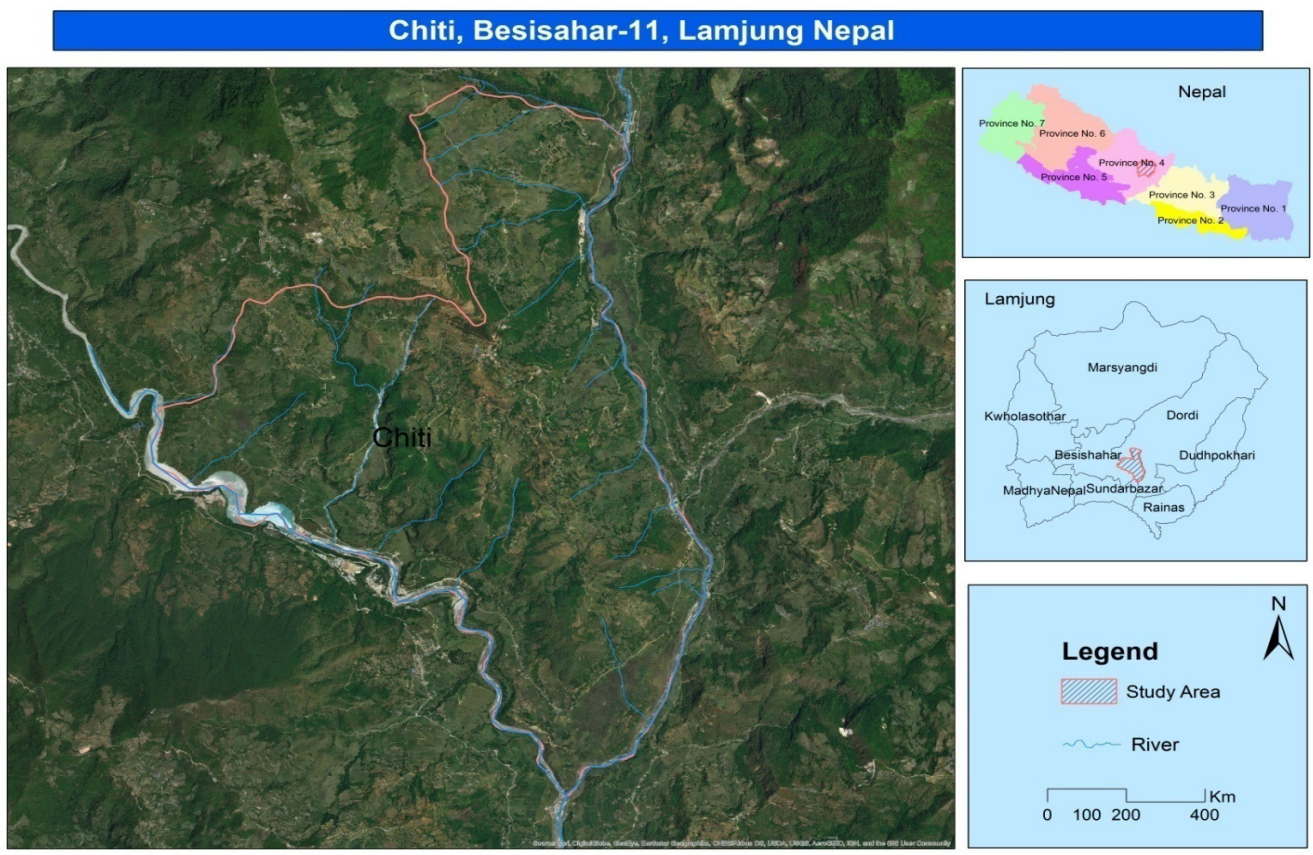

Figure 2: Location of the research site in Lamjung District, Nepal

In terms of accessibility, the area is located along the road side, merely half an hour drive from the district headquarters, Besishahar. Specifically, the south facing sub-watershed boundary of Chiti area has been selected as the study area which covers a total area of 1761.24 ha. with a total population of 5166 (CBS, 2011). 


\section{Landform of Chiti, Besisahar-11, Lamjung Nepal}
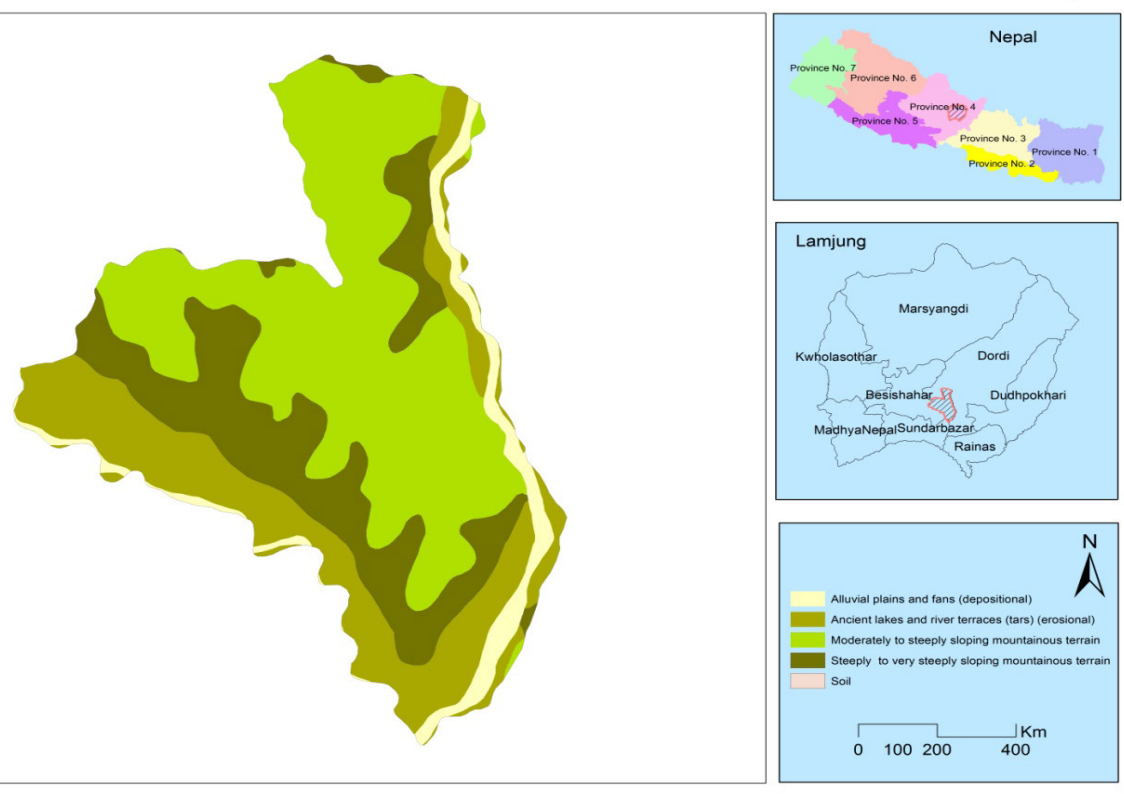

Figure 3: Landforms of the study area

Table 3: Characteristics of the landforms in the study area

\begin{tabular}{|l|r|r|}
\hline \multicolumn{1}{|c|}{ Landforms } & Area in ha. & Percent \\
\hline Moderately to steeply sloping mountainous terrain & 823.72 & 46.74 \\
\hline Steeply to very steeply sloping mountainous terrain & 419.25 & 23.79 \\
\hline Ancient lakes and river terraces (tars) (erosional) & 410.19 & 23.28 \\
\hline Alluvial plains and fans (depositional) & 109.08 & 6.19 \\
\hline Total & $\mathbf{1 7 6 2 . 2 4}$ & $\mathbf{1 0 0 . 0 0}$ \\
\hline
\end{tabular}




\section{Landuse of Chiti, Besisahar-11, Lamjung Nepal 1995}

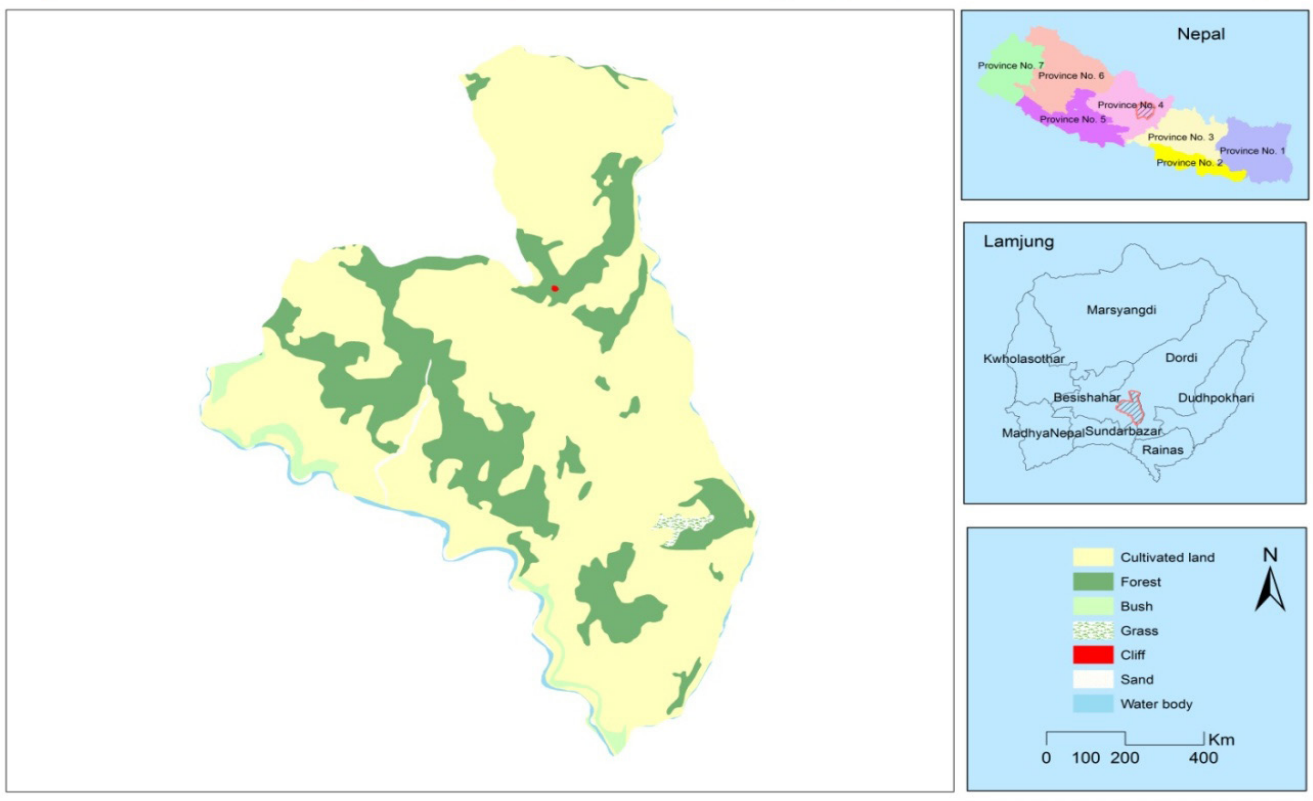

Figure 4: Land use of the study area

Agriculture is the dominant (74 percent) land use of the area followed by forest, bush, water area, sand and grass which are 22, 2, 1.2. 0.78 and 0.5 percent respectively. Moderate to steep sloping mountainous terrain, ancient lakes and river terraces (tars) and alluvial plains and fans are used as agriculture land and steep to very steep sloping mountainous terrain are used as forest, bush and grassland in the area.

This is one of the intervention sites of EbA South project on which attempt has been made for climate change resilient seedling plantation for reforestation and agro-forestry, bamboo suckers, banana and salix seedlings on degraded river bank and seedlings/ rhizomes/suckers in fruits orchards.

\section{Results and discussions}

\section{Exposure assessment}

Table 4 shows the exposure to climate change of the Chiti area from 2013 baseline household survey in comparison to long term monitoring household survey 2016, 2017 and 2019. 
Sher Bahadur Gurung/ Assessment of climate change vulnerability ...Vol. 14: 151-170, 2021

Table 4: Exposure index of climate change vulnerability

\begin{tabular}{|l|r|r|r|r|}
\hline \multicolumn{1}{|c|}{ Exposure } & \multicolumn{1}{c|}{$\mathbf{2 0 1 9}$} & \multicolumn{1}{c|}{ 2017 $^{*}$} & \multicolumn{1}{c|}{ 2016** $^{*}$} & \multicolumn{1}{c|}{$\mathbf{2 0 1 3}^{* * *}$} \\
\hline Minimum & 0.50 & 0.50 & 0.6 & 0.20 \\
\hline Maximum & 1.00 & 1.00 & 1.00 & 1.00 \\
\hline Average & 0.77 & 0.86 & 0.53 & 0.67 \\
\hline
\end{tabular}

Source: Field Study, 2019, * Rai, 2017; ** CDG, 2016; *** C4 EcoSolutions, 2013

The average index of exposure to climate change seems in increasing pattern from 2013 to 2019 with difference of 0.10 whereas it was highest (0.86) in 2017. Similarly, minimum was also rising and falling in all four study years. However, maximum exposure of climate change seems equal (1.00). The study of MoE, 2010 found that the exposure value of Lamjung district ranges from 0.580 to 1.0 and categorized it as very high exposure to climate change. The exposure value of $\mathrm{MoE}, 2010$ is close to long term monitoring exposure value. The DHM, 2016 data from 1985 to 2014 (Figure $5)$ also correspond with the changes in temperature and rainfall. The mean annual temperature was increased 0.037 degree Celsius per annum and average annual rainfall was decreased by $5.319 \mathrm{~mm}$ per year. The increasing trend of temperature is close to national figure of the country and the rainfall trend is severe than national situation.

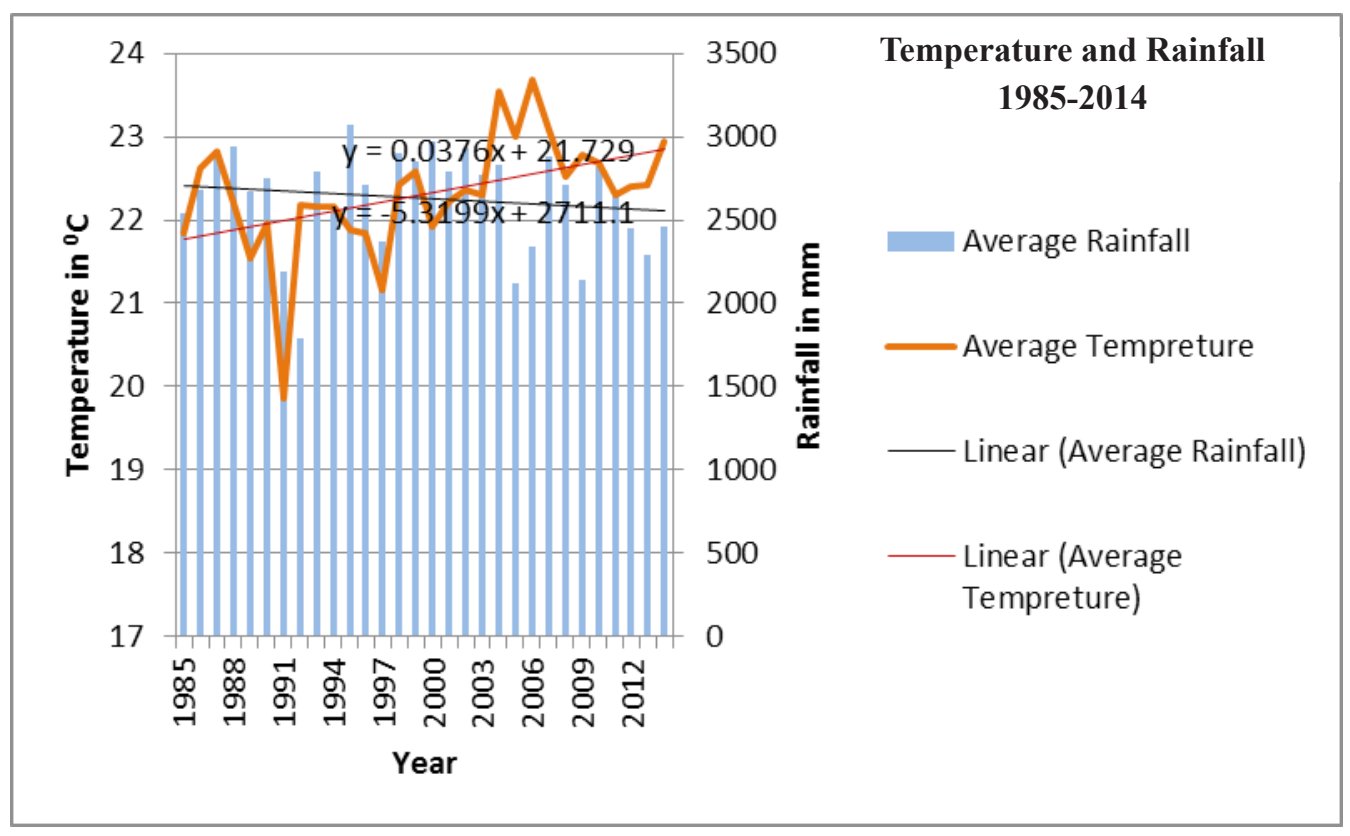

Figure 5: Exposure to Climate Change. Source: DHM, 2016 


\section{Sensitivity assessment}

Sensitivity is calculated based on slope failures, soil fertility, changes in natural environment (i) soil cover; ii) levels of river sedimentation; iii) water salinity; iv) river ecosystems; v) forest size; and vi) the presence of invasive species), economic dependency level, irrigation facilities and livelihood sources. The average value of assigned score is sensitivity index.

Table 5: Sensitivity index of climate change vulnerability

\begin{tabular}{|c|c|c|c|c|}
\hline Sensitivity & 2019 & 2017 * & 2016** & 2013 *** \\
\hline Minimum & 0.23 & 0.13 & 0.56 & 0.21 \\
\hline Maximum & 0.71 & 0.79 & 0.81 & 0.86 \\
\hline Average & 0.46 & 0.56 & 0.51 & 0.53 \\
\hline
\end{tabular}

Source: Field Study, 2019, * Rai, 2017; ** CDG, 2016; *** C4 EcoSolution, 2013

The average sensitivity index was observed 0.53 in 2013 and 0.46 in 2019 which shows slightly improved situation in 2019. Similarly, the minimum index was 0.21 in baseline year 2013 and it is 0.23 in 2019. Maximum sensitivity index was observed better in 2019 than 2013. The sensitive score of the Lamjung district was ranged from 0.21 to 0.301 (MOE, 2010). The minimum value is similar to baseline household survey and long term household survey but the maximum score is higher in Chiti area than the district. It shows that the household and community of this area experienced changes on natural resources by climate change and impact on it (see Figure $6 a$ and b).

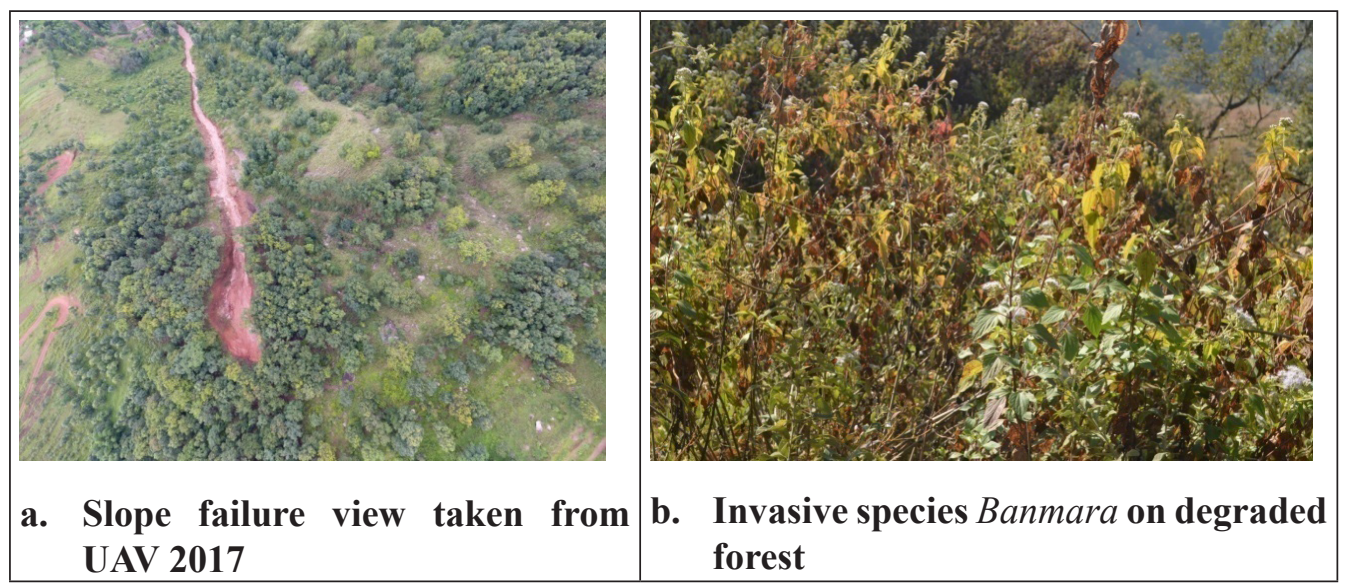

Figure 6: Sensitivity to climate change 


\section{Adaptive capacity assessment}

Climate change adaptive capacity is a result of awareness, information on climate change and adaptation, surplus production and change in agricultural practices. The average score of assigned value is adaptive capacity index. The household with 60 to 100 percent awareness; updated with the information of climate change and adaption; selling more than 30 percent surplus production; and responding climate change by adapting new agricultural practices has been scored as 2 .

Table 6: Adaptive capacity index of climate change

\begin{tabular}{|c|r|r|r|r|}
\hline Adaptive Capacity & \multicolumn{1}{|c|}{$\mathbf{2 0 1 9}$} & \multicolumn{1}{c|}{$\mathbf{2 0 1 7}^{*}$} & \multicolumn{1}{c|}{$\mathbf{2 0 1 6}^{* *}$} & \multicolumn{1}{c|}{$\mathbf{2 0 1 3}^{* * *}$} \\
\hline Minimum & 0.25 & 0.25 & 0.00 & 0.00 \\
\hline Maximum & 1.00 & 1.00 & 0.75 & 0.67 \\
\hline Average & 0.63 & 0.6 & 0.12 & 0.13 \\
\hline
\end{tabular}

Source: Field study, 2019, * Rai, 2017; ** CDG, 2016; *** EcoSolution, 2013

The table 6 shows that the average adaptive capacity index for climate change has been improved in 2019 in compared to 2013 and 2016. It is assumed that it could be due to the result of EbA south supported agro forestry high value plantation. Minimum index was 0.00 in 2013 and 0.25 in 2019. Likewise, maximum was 0.67 in 2013 and it is 1.00 in 2019 which has been increased due to the adaptive capacity. The adaptive capacity of the Lamjung district was ranged from 0.167 to 0.336 . These values are almost close to the baseline household survey and less than long term monitoring household survey of Chiti area. It is also assumed as the result of enhancement of climate change adaptive capacity through awareness and adaptation through new agricultural practices (Figure $7 \mathrm{a}, \mathrm{b}, \mathrm{c}, \mathrm{d}, \mathrm{e}$, and f). 

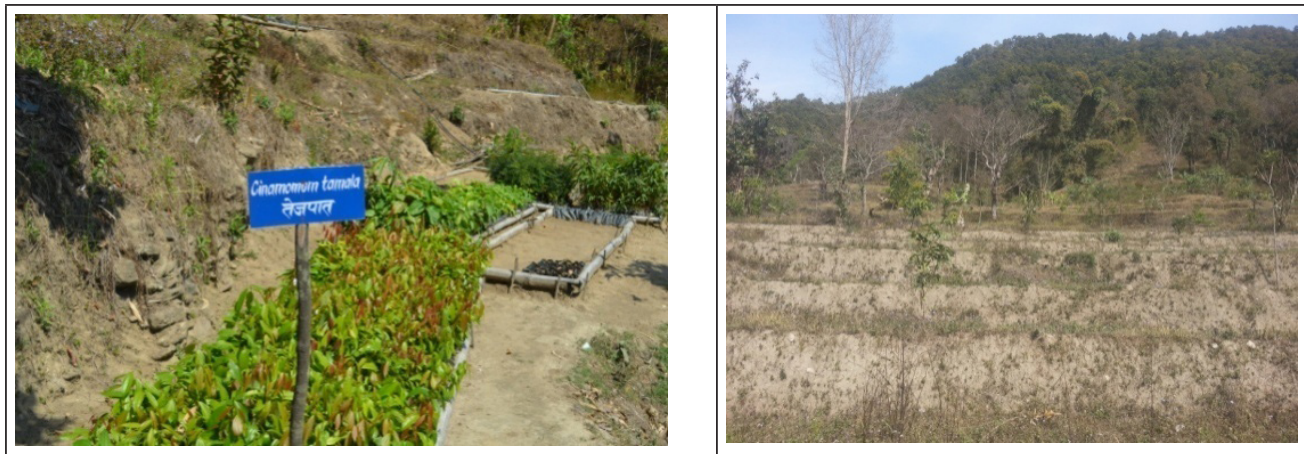

a. Nursery for agro-forestry and horticulture

b. Planting mango and litchi
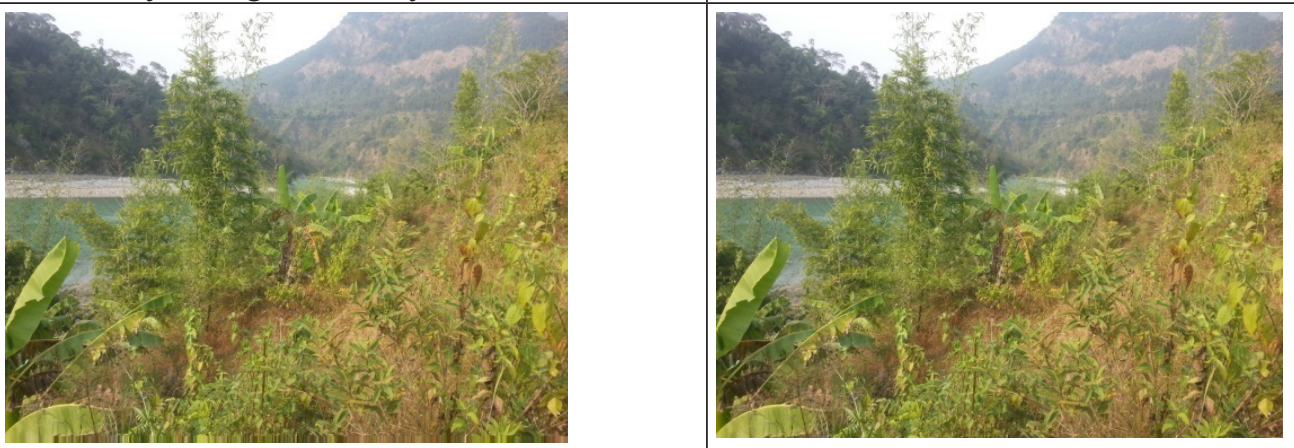

c. Ginger cultivation for income generation

d. Bamboo and banana plantation for income generation and slope protection

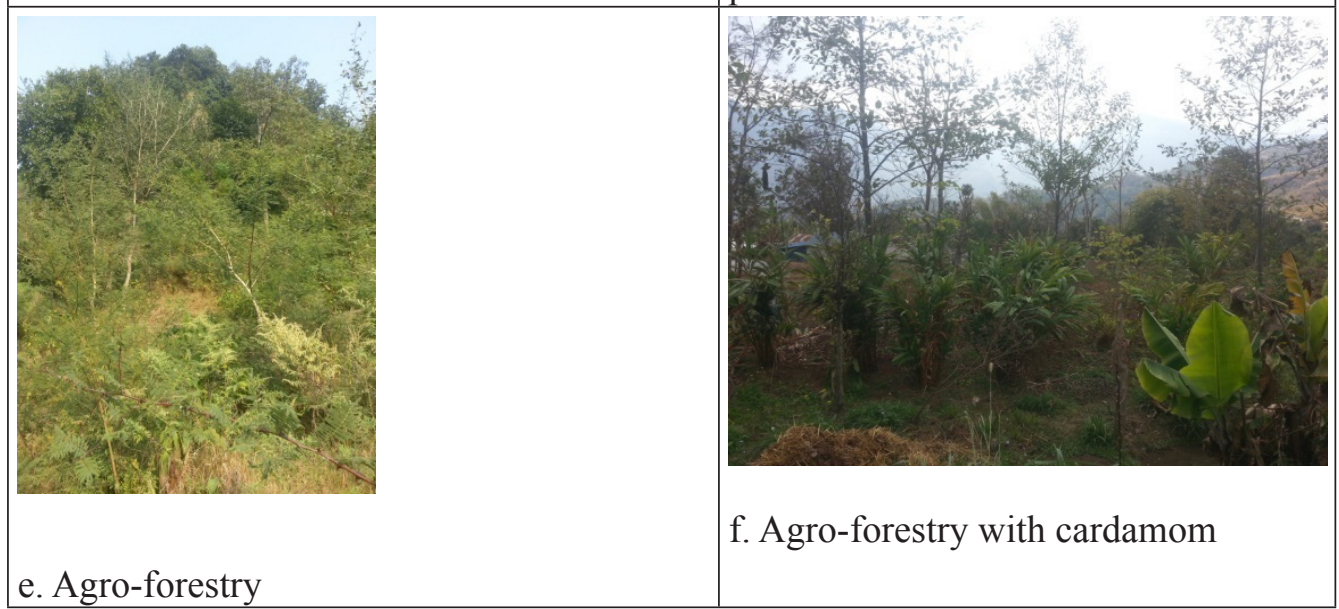

Figure 7: Climate change adaptation practices in the study area 


\section{Awareness assessment}

Awareness score has been calculated based on conceptual awareness, experiential awareness, and engagement of household to talk about climate change and adaptation. They understood about drivers of climate change and its effect in depth, gave in-depth examples and talked about climate change more than once a week scored 3. The average score of awareness index is changed into the percent.

Table 7: Awareness score of climate change

\begin{tabular}{|c|r|r|r|r|r|}
\hline Awareness & \multicolumn{1}{|c|}{$\mathbf{2 0 1 9}$} & \multicolumn{1}{c|}{$\mathbf{2 0 1 7}^{*}$} & $\mathbf{2 0 1 6}^{* *}$ & $\mathbf{2 0 1 5}^{* * *}$ & $\mathbf{2 0 1 3}^{* * * *}$ \\
\hline Minimum & 44.44 & 11.11 & 0.00 & - & 0.99 \\
\hline Maximum & 100.00 & 77.78 & 77.78 & - & 78.00 \\
\hline Average & 72.02 & 39.56 & 34.16 & 28.00 & 16.00 \\
\hline
\end{tabular}

Source: Field study, 2019, * Rai, 2017; ** CDG, 2016; *** Kaplan and Mills, 2015; *****EcoSolution, 2013

The data in table 7 shows average awareness score of climate change which is in increasing trend during four study periods. It has been increased more than four times in 2019 than 2013. It could be due to the reason of frequent visit and asking same questions by researchers with the same respondents. Similarly, the Hariyoban program of WWF support had lunched three months long climate change training program in 2018 side by side for the local people in the study area. As a result, the minimum and maximum score have also been observed in improving trend.

\section{Vulnerability assessment}

Vulnerability is calculated based on EbA South 2013 i.e. Vulnerability $=($ Exposure * Sensitivity) - Adaptive capacity 
Table 8: Vulnerability index of climate change

\begin{tabular}{|c|r|r|r|r|}
\hline Vulnerability & \multicolumn{1}{c|}{$\mathbf{2 0 1 9}$} & \multicolumn{1}{c|}{$\mathbf{2 0 1 7}^{*}$} & \multicolumn{1}{c|}{$\mathbf{2 0 1 6}^{* *}$} & \multicolumn{1}{c|}{$\mathbf{2 0 1 3}^{* * *}$} \\
\hline Minimum & -0.68 & -0.61 & -0.18 & -0.47 \\
\hline Maximum & 0.32 & 0.29 & 0.73 & 0.77 \\
\hline Average & -0.27 & -0.16 & 0.34 & 0.25 \\
\hline
\end{tabular}

Source: Field study, 2019, * Rai, 2017; ** CDG, 2016; *** Ecosolution, 2013

The average vulnerability index of climate change is -0.27 in 2019 whereas it was 0.25 in 2013 which shows the improving condition of vulnerability in 2019 (Table 8). Even the minimum value was in good condition during all the study years. Maximum index was 0.77 in 2013 and it is 0.32 in 2019 which ranged from 0.787 to 1.0 (MoE, 2010) which is very high in comparison to the baseline 2013 and long term monitoring index because of improvement of climate change adaptive capacity in the study area (See Figure 7).

\section{Conclusion}

Chiti area of Lamjung has been experiencing climate change vulnerability. The paper dealt with serious environmental problems (climatic change phenomena) and its impact on the community in the area. IPCC methodology has been used to analyse the variables such as exposure, sensitivity, and adaptive capacity in relation to the short-term and long-term effects of EbA South interventions on climate change impact within the area. In short-term, climate change awareness among the households has been increased in the area which reduced the climate change vulnerability consequently. However, for the long term impact study requires longer monitoring. The study findings based on post adaptation vulnerability analysis of local community could be useful for national climate change vulnerability adaptation policy.

\section{Acknowledgements}

This article is based on the information collected from the field work supported by Ecosystem Based Adaptation through South-South Cooperation (EbA South) project funded by the Global Environment Facility, implemented by the United Nations Environment Program and executed by the National Development and Reform Commission of China through the Institute of Geographic Science and Natural Resources Research, Chinese Academy of Sciences. The author is grateful to all the institutions and persons for their valuable support. 
Sher Bahadur Gurung/ Assessment of climate change vulnerability ...Vol. 14: 151-170, 2021

\section{References}

Adhikari, B. (2016). Climate change and its impact on livelihood (A case study of Chiti, Jita and Taksar VDC of Lamjung district). Unpublished Dissertation, Tribhuvan University.

C4 EcoSolitions (2013). Baseline assessment for project: Enhancing capacity, knowledge and technology Support to build climate resilience of vulnerable developing countries, Ecosystem-based Adaptation through South -South Cooperation (EBA SSC). C4 EcoSolitions, Captown, South Africa.

CBS (2012). National population and household census 2011: Village Development Committee/Municipality, Volume 02. Kathmandu: Central Bureau of Statistics, Nepal.

CDG (2016). Climate change awareness and vulnerability assessment in Chiti and Jita/Taksar Pilot sites of Ecosystem-based Adaptation through South-South Cooperation, EbA South: Enhancing Capacity, Knowledge and Technology Support to Build Climate Resilience of Vulnerable Developing Countries. Kathmandu: Central Department of Geography, Nepal.

DHM (2017). Observed climate trend analysis of Nepal (1971-2014). Kathmandu: Department of Hydrology and Metrology, Ministry of Population and Environment, Government of Nepal.

Gentle, P., Thwaites, R., Race, D. \& Alexander, K. (2014). Differential impacts of climate change on communities in the middle Hills region of Nepal. Nat Hazards. 74 PP.815-836.

Hijioka, Y., Lin, E., Pereira, J.J., Corlett, R.T., Cui, X., Insarov, G.E., Lasco, R.D., Lindgren, E. \& Surjan, A. (2014). Asia in climate change 2014: Impacts, adaptation, and vulnerability. Part B: Regional Aspects. Contribution of Working Group II to the Fifth Assessment Report of the Intergovernmental Panel on Climate Change [Barros, V.R., C.B. Field, D.J. Dokken, M.D. Mastrandrea, K.J. Mach, T.E. Bilir, M. Chatterjee, K.L. Ebi,Y.O. Estrada, R.C. Genova, B. Girma, E.S. Kissel, A.N. Levy, S. MacCracken, P.R. Mastrandrea, and L.L. White (eds.)]. New York: Cambridge University Press, pp. 1327-1370.

IPCC (2018). Summary for policy makers. In: Global Warming of $1.5^{\circ} \mathrm{C}$. An IPCC Special Report on the impacts of global warming of $1.5^{\circ} \mathrm{C}$ above pre-industrial 
levels and related global greenhouse gas emission pathways, in the context of strengthening the global response to the threat of climate change, sustainable development, and efforts to eradicate poverty [Masson-Delmotte, V., P. Zhai, H.-O. Pörtner, D. Roberts, J. Skea, P.R. Shukla, A. Pirani,W. Moufouma-Okia, C. Péan, R. Pidcock, S. Connors, J.B.R. Matthews, Y. Chen, X. Zhou, M.I. Gomis, E. Lonnoy,T. Maycock, M. Tignor, and T. Waterfield (eds.)]. Geneva: World Meteorological Organization, pp. 32

IPCC (2014). Summary for policymakers. In: Climate Change 2014: Impacts, Adaptation, and Vulnerability.Part A: Global and Sectoral Aspects. Contribution of Working Group II to the Fifth Assessment Report of the Intergovernmental Panel on Climate Change [Field, C.B., V.R. Barros, D.J., Dokken, K.J., Mach, M.D., Mastrandrea, T.E., Bilir, M. Chatterjee, K.L., Ebi, Y.O., Estrada, R.C., Genova, B., Girma, E.S., Kissel, A.N. Levy, S., MacCracken,P.R., Mastrandrea, T. E. \& White, L.L. (2013). New York: Cambridge University Press, pp. 1-32.

IPCC (2001). Climate change 2001: Impacts, adaptation, and vulnerability. Intergovernmental Panel on Climate Change, IPCC, Edinburg: Cambridge University Press.

Kaplan, B. and Mills A. (2015). Rapid assessment report for the EBA South Project for Lamjung District Nepal. Captown: C4 EcoSolitions.

MoE (2010). Climate change vulnerability mapping for Nepal. Kathmandu: Ministry of Environment, MoE.

MoPE (2017). Vulnerability and risk assessment framework and indicators for national adaptation plan (NAP) formulation process in Nepal. Kathmandu: Ministry of Population and Environment.

Rai, K. (2017). Assessing the changes in vulnerability condition in EbA project site, Lamjung district, Nepal. Unpublished Dissertation, Tribhuvan University.

Tsering, K., Sharma, E., Chettri, N., \& Shrestha, A. (2010). Climate change impact and vulnerability in the eastern Himalaya. Synthesis report on climate change vulnerability of mountain ecosystem in the eastern Himalayas. Kathmandu: International Centre for Integrated Mountain Development. 
Sher Bahadur Gurung/ Assessment of climate change vulnerability ...Vol. 14: 151-170, 2021

(Footnotes)

1. Changes in natural environment are related to the household-survey questionnaire. This indicator is estimated by households reporting changes in: i) soil cover; ii) levels of river sedimentation; iii) water salinity; iv) river ecosystems; v) forest size; and vi) the presence of invasive species.

2. Dependency level is measured by household size.

3. See this section for details on the calculation of the awareness index. 